\title{
THE SCIENTIFIC PRODUCTION OF BRAZILIAN NEUROLOGISTS: 1995-2004
}

\author{
Ricardo Nitrini ${ }^{1}$
}

\begin{abstract}
The Brazilian scientific production saw more than a four-fold increase from the 1990s onwards. The aim of this study was to evaluate the evolution of scientific production by Brazilian clinical neuroscientists over the last 10 years. A search in the PubMed identified 295 clinical neuroscientists and their publications. Brazilian production corresponded to $2.37 \%$ of the papers published by the 20 indexed periodicals that regularly publish clinical neuroscience research. If only the first and last two years are compared, there was a real growth of $75.1 \%$. More than $40 \%$ of the Brazilian papers were published in Arquivos de Neuro-Psiquiatria, the official journal of the Brazilian Academy of Neurology. When only those periodicals with impact factor higher than one are considered, the percentage falls to $0.86 \%$ in the whole 10 -year period, but attains $1.23 \%$ in 2004. Epilepsy and infectious diseases were the sub-areas with the highest scientific production.
\end{abstract}

KEY WORDS: Brazilian neurologists, scientific production, clinical neuroscientists.

\section{Produção científica dos neurologistas brasileiros: 1995-2004}

RESUMO - A produção científica brasileira mais do que quadruplicou desde 1990. O objetivo deste estudo foi avaliar a evolução da produção dos neurocientistas clínicos brasileiros nos últimos 10 anos. Pesquisa realizada no PubMed identificou 295 neurocientistas clínicos e suas publicações. A produção brasileira re presentou $2,37 \%$ dos artigos publicados pelos 20 periódicos indexados que regularmente publicam pesquisas em neurociência clínica. Quando somente os primeiros e últimos dois anos forem comparados houve crescimento real de $75,1 \%$. Mais de $40 \%$ dos artigos brasileiros foram publicados em Arquivos de Neuro-Psiquiatria, o jornal oficial da Academia Brasileira de Neurologia. Quando apenas periódicos com fator de impacto superior a 1 foram considerados, a porcentagem caiu para $0,86 \%$ no período total, mas atingiu 1,23\% em 2004. Epilepsia e doenças infecciosas foram as subáreas com a maior produção científica.

PALAVRAS-CHAVE: neurologistas brasileiros, produção científica, neurocientistas clínicos.

The Brazilian scientific production evaluated by the number of scientific publications in periodicals indexed at the Institute for Scientific Information (ISI) has grown significantly, mainly from the 1990s onwards, when it saw more than a four-fold increase'. In the period 1998-2002, the number of publications by Brazilian scientists indexed in the SCIE increased from $1.1 \%(10,279$ papers $)$ in 1998 , to $1.5 \%(15,846$ papers) in 2002. This $54.2 \%$ growth was much higher than the overall world production growth of $8.7 \%$ over the same period.

In 1981, the Brazilian scientific production rep resented only $0.2 \%$ of world production ${ }^{2}$. In the period 1998-2002, the number of publications by Brazilian scientists indexed in the SCIE increased from $1.1 \%$ $(10,279$ papers) in 1998 , to $1.5 \%$ (15,846 papers) in 2002. This $54.2 \%$ growth was much higher than the overall world production growth of $8.7 \%$ over the same period. The leading countries in this period were the United States (32.2\% of total indexed publications), Japan $(8.3 \%)$, Germany $(7.8 \%)$, England (7.5\%) and France $(5.6 \%)$, while China, with $3.1 \%$ of world production, had the highest growth rate $(103.0 \%)^{2}$.

The other Latin America countries, in particular Mexico, Argentina and Chile, have also had high rates of growth in their scientific production, but not as high as Brazil's. Mexican scientific production, for example, was the highest among these three countries, but attained less than $0.6 \%$ of overall world production in $2002^{2}$.

The areas of knowledge with the highest scientific production in Brazil were Medicine, which accounted for about $25 \%$ of the Brazilian publications

\footnotetext{
${ }^{1}$ Associate Professor of Neurology, Department of Neurology, University of São Paulo School of Medicine, São Paulo SP, Brazil.
} 
indexed in the SCIE in the 1998-2002 period, followed by Physics with $15 \%$, and Chemistry with about $10 \%{ }^{2}$.

Several papers have evaluated the Brazilian scientific production on clinical neurosciences. SpinaFrança verified that in 1991 and 1992, Brazilian papers in the Journal of the Neurological Sciences, the off $i-$ cial journal of the World Federation of Neurology, corresponded to $1 \%$ of the total number of papers published in the period, a rate comparable to that of Argentina and South Africa ${ }^{3}$. Bacheschi and Guerre i ro stated that the production of Brazilian clinical $n$ e u roscientists has increased greatly in recent years, and established a distinction between clinical neuroscientists, whose research focus was on clinical activity, carrying out observational studies or clinical trials, and basic neuroscientists who work in the laboratory or do experimental research ${ }^{4}$.

Knowing the quantity and evolution of Brazilian scientific production on clinical neurosciences is relevant to the research support agencies, the academic institutions and the Brazilian Academy of Neurology.

The aim of this study was to evaluate the evolution of scientific production by Brazilian clinical neuroscientists over the last 10 years.

\section{METHOD}

In order to identify the Brazilian clinical neuroscientists, an e-mail was sent to the Brazilian Academy of Neurology requesting the names of members of its scientific departments. The scientific production of each of the members was first sought from the Curriculum Vitae available at the Lattes Platform of the National Research Council (Conselho Nacional de Pesquisa - CNPq) whilst it was also investigated whether there were other researchers identified as neurologists or clinical neuroscientists who had not been included in the files of the Brazilian Academy of Neurology.

The scientific publication of each of the neurologists in the period 1995-2004 was then searched for in the PubMed, the U.S. National Institutes of Health, free digital archive of biomedical and life sciences journal literature. Other re se a rchers, among them basic neuroscientists, were not included in this survey.

Only scientific production indexed in the PubMed database was evaluated in this study. The name of each author, with his/her publications, either as the main author or coauthor, with their titles, names of the periodical, and full refe rence were compiled in an Excel file. The impact factor of each periodical was obtained from the Web of Science (www. webofscience.com/http:/isikwnowledge.com/journal citation re ports accessed in July 22, 2005)and was also included in the Excel file. Each publication was included only once, and was classified under one of the sub-areas of neurology. When a publication could be classified as belonging to more than one area, it was classified under one, according to the main research interest of the principal author.

To verify the numbers and proportion of Brazilian pro- duction in clinical neurosciences in relation to world scientific production in this field, the 20 indexed periodicals, which had impact factors available and that regularly publish clinical neuroscience research and in which Brazilian papers had been published were identified. Furthermore, the number of papers published by each periodical each year along with how many of these had been produced by Brazilian clinical neuroscientists were determined.

\section{RESULTS}

The list sent by the Brazilian Academy of Neurology contained 749 members in its 17 scientific departments. Only 148 were registered in the Lattes Platform of the National Research Council. In this database, another 15 clinical re se a rchers registered as neurologists, but who were not members of the Brazilian Academy of Neurology, were also identified and included in the survey. Another 132 members of the Brazilian Academy of Neurology not registered in the Lattes Platform had publications indexed in the PubMed. The final number of clinical neuroscientists included in this survey was 295 .

The numbers of publications by these 295 clinical ne u roscientists indexed in the PubMed over the period 1995-2004 are shown in Table 1.

The rewas a steady growth in the number of publications in indexed journals. In the first five years of the period, 683 (37.0\%) papers were published, while in the final five years $1162(63.0 \%)$ were published, representing a $70.1 \%$ increase. If only the first and last two years are considered, this increase would be of $127.6 \%$.

Table 1. Scientific production by Brazilian clinical neuroscien tists (PubMed; 1995-2004).

\begin{tabular}{ccc}
\hline Year & Number of publications & $\%$ \\
\hline 1995 & 123 & 6.7 \\
1996 & 105 & 5.7 \\
1997 & 153 & 8.3 \\
1998 & 152 & 8.2 \\
1999 & 150 & 8.1 \\
2000 & 190 & 10.3 \\
2001 & 215 & 11.7 \\
2002 & 238 & 12.9 \\
2003 & 226 & 12.2 \\
2004 & 293 & 15.9 \\
Total & 1845 & 100 \\
\hline
\end{tabular}


Table 2. Twenty periodicals with highest number of papers published by Brazilian clinical neuroscientists in the 19952004 period, showing number of papers, percentage of total number of Brazilian papers, impact factor and total num ber of published papers.

\begin{tabular}{|c|c|c|c|c|}
\hline Name of the periodical & $\begin{array}{l}\text { N (Brazilian } \\
\text { papers) }\end{array}$ & $\%$ & $\begin{array}{l}\text { Impact } \\
\text { factor }\end{array}$ & $\stackrel{\mathrm{N}}{0 \text { (total) }}$ \\
\hline Arquivos de Neuro-Psiquiatria & 769 & 41.7 & 0.401 & 1776 \\
\hline Neurology & 80 & 4.3 & 5.973 & 11435 \\
\hline Epilepsia & 44 & 2.4 & 3.329 & 2912 \\
\hline Cephalalgia & 36 & 2.0 & 3.133 & 1343 \\
\hline Brazilian Journal of Medical and Biological Research & 31 & 1.7 & 0.824 & 2112 \\
\hline Archives of Neurology & 28 & 1.5 & 4.835 & 2479 \\
\hline Headache & 24 & 1.3 & 2.307 & 1475 \\
\hline Annals of Neurology & 22 & 1.2 & 8.097 & 2946 \\
\hline Journal of the Neurological Sciences & 22 & 1.2 & 2.366 & 2654 \\
\hline Movement Disorders & 21 & 1.1 & 3.093 & 2380 \\
\hline Acta Neurologica Scandinavica & 18 & 1.0 & 1.712 & 1505 \\
\hline Journal of Neurology Neurosurgery and Psychiatry & 16 & 0.9 & 3.110 & 4726 \\
\hline Muscle \& Nerve & 14 & 0.8 & 2.432 & 2709 \\
\hline Epilepsy Research & 14 & 0.8 & 2.897 & 1080 \\
\hline Brain & 12 & 0.6 & 8.201 & 2086 \\
\hline Brain \& Development & 12 & 0.6 & 1.382 & 1865 \\
\hline Clinical Neurophysiology & 12 & 0.6 & 2.538 & 1660 \\
\hline Pediatric Neurology & 12 & 0.6 & 1.184 & 1415 \\
\hline Journal of Child Neurology & 10 & 0.5 & 1.333 & 1642 \\
\hline Epilepsy \& Behavior & 9 & 0.5 & 1.630 & 688 \\
\hline Total & 1206 & - & - & 50888 \\
\hline
\end{tabular}

The 20 journals that regularly publish papers by these Brazilian clinical neuroscientists are listed in Table 2.

Brazilian production corresponded to $2.37 \%$ of world production in the field during the period.

When only those periodicals with impact factors higher than one were selected, according to the usual procedure of CAPES (Coordenadoria de Aperfeiçoamento do Pessoal do Ensino Superior), an Agency of the Brazilian Ministry of Education responsible for evaluation of teaching and research institutions in Brazil, increasing growth in production is also verified (Table 3).

In the first five years, 152 papers were published $(0.75 \%$ of the total number of published papers), while in the second quinquennium 254 papers were published $(0.95 \%)$, a growth of $26.7 \%$. If only the first and last two years are considered, the incre ase would be $75.1 \%$.

The classification of the papers into the sub-areas of Neurology is depicted in Table 4.

\section{DISCUSSION}

Bacheschi and Guerre i ro (2004) estimated that 5 to $10 \%$ of the almost 2500 Brazilian neurologists could be considered clinical neuroscientists ${ }^{4}$. In this study, 295 clinical neuroscientists were identified, corresponding to $11.8 \%$ of the 2500 Brazilian neurologists, con$\mathrm{fi}$ rming estimates made by these authors. This study also confirms the assumed increase in the number of publications, mainly when the two last years are comp a red with the two first years of the period, where there was an increase of $127.6 \%$. However, it should 
Table 3. Number and percentage of Brazilian publications from total number of publications in periodicals with impact fac tors higher than 1.0.

\begin{tabular}{cccc}
\hline Year & $\begin{array}{c}\text { N (Brazilian } \\
\text { papers) }\end{array}$ & $\begin{array}{c}\mathrm{N} \\
\text { (Total) }\end{array}$ & $\%$ \\
\hline 1995 & 21 & 3570 & 0.59 \\
1996 & 25 & 3911 & 0.64 \\
1997 & 43 & 3837 & 1.12 \\
1998 & 30 & 4330 & 0.69 \\
1999 & 33 & 4734 & 0.69 \\
2000 & 34 & 5189 & 0.65 \\
2001 & 54 & 5052 & 1.07 \\
2002 & 46 & 5230 & 0.88 \\
2003 & 49 & 5389 & 0.91 \\
2004 & 71 & 5758 & 1.23 \\
Total & 406 & 47000 & 0.86 \\
\hline
\end{tabular}

be taken into account that world scientific production has also increased in the period ${ }^{2}$.

When the analysis focuses on those periodicals in which Brazilian papers are more often published, Arquivos de Neuro-Psiquiatria ranks as the most important. More than $40 \%$ of all papers by Brazilian clinical neuroscientists were published here in the period. This periodical, the official journal of the Brazilian Academy of Neurology, has an increasing impact factor and has been very important for the publication of the research done by Brazilian clinical neuroscientists. As Arquivos de Neuro-Psiquiatria participates in the Scielo (Scientific Electronic Library Online), its publications are freely available online, allowing immediate dissemination of the Brazilian production in the field. Other journals, such as Neurology, Annals of Neurology, Archives of Neurology, and also journals with more restricted areas of interest, such as Epilepsia, Cephalalgia, Headache and Movement Disorders, publish a considerable and increasing number of papers by Brazilian neuroscientists.

Brazilian production corresponded to $2.37 \%$ of world scientific production in the area, according to data from the 20 periodicals in which Brazilian clinical neuroscientists usually publish their papers. When only those periodicals with impact factor higher than 1 are considered, the percentage falls to $0.86 \%$ in the whole 10-year period, but attains $1.23 \%$ in 2004 .
Table 4. Number of papers under each sub-area of Neurology.

\begin{tabular}{lcc}
\hline Sub-area of Neurology & $\mathrm{N}$ & $\%$ \\
\hline Epilepsy & 325 & 17.6 \\
Infectious diseases & 243 & 13.2 \\
Headache & 145 & 7.90 \\
Cerebrovascular diseases & 140 & 7.6 \\
Movement Disorders & 123 & 6.7 \\
Muscle diseases & 119 & 6.4 \\
Cognitive Disorders & 106 & 5.7 \\
Neuropediatrics & 104 & 5.6 \\
Peripheral neuropathies & 88 & 4.8 \\
Neurogenetics & 57 & 3.1 \\
Multiple sclerosis & 51 & 2.8 \\
Neuro-oncology & 42 & 2.3 \\
Neuroimage & 42 & 2.3 \\
Clinical Neurophysiology & 34 & 1.8 \\
Other areas and/or unclassified papers & 226 & 12.2 \\
\hline
\end{tabular}

This percentage probably places production of Brazilian clinical neuroscientists close to mean total Brazilian scientific production, which was, as mentioned earlier, stood at $1.5 \%$ of world production in 2002. When Brazilian and world production on clinical neuroscience were compared, there was a real $\mathrm{g}$ rowth of $75.1 \%$ in Brazilian production from 19951996 to 2003-2004.

In spite of this impressive growth, the percentage is still low and indicates that efforts are required to improve the scientific production of Brazilian clinical neuroscientists. One of the possible strategies to accomplish this task could be to encourage the residents to participate in publications of scientific papers during their residence program. This would train the neurdogists enabling them to publish their own data in the future.

The method employed to compare Brazilian to world production on clinical neuroscience was developed especially for this study. Simply listing all journals that can publish clinical neuroscience papers seemed inadequate, leading to too much uncertainty over whether to include a given journal or not. The selection of 20 journals $(18$, when two with impact factor less than 1.0 were excluded) very probably included the most highly respected periodicals in the field. 
With regardto Neurology sub-areas, it was possible to identify epilepsy and infectious diseases as those with the highest scientific production in Brazil, although there are a considerable number of papers on every main Neurology sub-area.

Evaluation of scientific production based on the number of published papers, even only in periodicals indexed in PubMed, may be criticized because the reare large diffe rences among these periodicals ${ }^{5}$. The number of citations obtained by each paper might have been a more refined, but a much more time-consuming, way of analyzing the production. On the other hand, papers that were published in journal indexed only in SciElo or in the Latin American and Caribbean Health Sciences Literature (LILACS database ), as well as books and chapters of books, were not included in this survey. Thus, a considerable proportion of Brazilian scientific production in this field was not evaluated. Evaluation of scientific production by region, state or research institution was also not included in the objectives of this study. In spite of these limitations the data of this study may be useful for analyzing the production of Brazilian clinical neuroscientists, to establish comparisons with other countries, and most important, to track evolution in the near future.

It would be unfair to conclude without mentioning that the growth in Brazilian publications is largely due to the development of the post-graduate programs in the country ${ }^{2}$ and to the strict criteria that have been used by CAPES in the annual evaluation of these programs.

Acknowledgement - I wish to thank Alair Mariana dos Santos Silva for the help in the data collection from Lattes Platform and PubMed.

\section{REFERENCES}

1. PinheiroMachado R, Oliveira PL. The Brazilian investment in science and technology. Braz J Med Biol Res 2001;34:1521-1530.

2. Fundação de Ampa roà Pesquisa do Estado de São Paulo - FAPESP. Analysis of scientific production based on bibliometric indicators. In: science, technology \& innovation Indicators in the State of São Paulo/Brazil, 2004 (www:fapesp.br/indicadores; accessed in December 2005)

3. Spina-França A. Estado atual das neurociências no Brasil. Neuro-Press 1997;1:3-5.

4. Bacheschi LA, Guerrei ro CAM. Situação das neurociências no Brasil: neurociências clínicas. Ciência \& Cultura 2004;56:25-26.

5. Lin a rdiPM, Coelho PMZ, Costa HMA. The "impact factor" as a criterion for the quality of scientific production is a relative, not absolute, measure. Braz J Med Biol Res 1996; 29:555-561. 